УДК 355.34:94 [477]

СЛЮСАРЕНКО А. В.

https://orcid.org/0000-0001-7812-6277

https://doi.org/10.33577/2313-5603.31.2019.164-178

\title{
СИЛИ СПЕЦІАЛЬНОГО ПРИЗНАЧЕННЯ ЗБРОЙНИХ СИЛ КИТАЮ: СУЧАСНИЙ ЕТАП РОЗВИТКУ ТА ПЕРСПЕКТИВИ
}

Аналізується військова історія створення та діяльності Сил спеціального призначення (ССП) Збройних сил Китайської Народної Республіки (КНР). Відзначається, що на зламі XX - початку XXI століть зроблено якісний стрибок у модернізації найбільшої армії світу. У січні 2016 р. у КНР було оголошено про початок масштабного реформування збройних сил, кінцевою метою якого $є$ досягнення до 2020 р. нового рівня керованості, оптимальної структурної побудови й забезпечення здатності армії здобувати перемогу в епоху інформаційних технологій. Описується технічне оснащення ССП, їх бойова навченість. Підкреслюється, що Китай поки що не запроваджує єдиний орган управління ССП. Спеціальна підготовка стала елементом боєготовності й у звичайних військах, їх об'єднаннях і з'єднаннях, що різко підвищує потенціал армії Китаю у разі ведення «асиметричної» війни.

Ключові слова: Китайська Народна Республіка, Народно-визвольна армія Китаю, Сили спеціальних операцій Китаю, Сухопутні війська КНР.

Китайська Народна Республіка, про важливість плідних відносин з якою неодноразово заявляли керівники України, стрімко набуває статусу «першої економіки» світу, лідера інноваційного розвитку, перетворилася на потужний чинник світового розвитку й співвідношення сил у світі та в Азіатсько-Тихоокеанському регіоні (АТР) зокрема. Як заявив на XIX з’їді Комуністичної партії Китаю (КПК) іiі Голова Сі Цзіньпін, «Китай наближається до того, щоб стати центром світової сцени. До 2050 року ми станемо глобальним лідером із загальної сили нації й міжнародного впливу». Прагнучи до беззаперечного лідерства в АТР, Китайська Народна Республіка (КНР), разом $з$ тим активно бере участь у міжнародному співробітництві з питань безпеки, реалізує «Концепцію безпеки нового типу, засновану на міждержавній довірі».

Слюсаренко Андрій Віталійович, кандидат історичних наук, доцент, заступник начальника Національної академії сухопутних військ України імені гетьмана Петра Сагайдачного з наукової роботи, м. Львів.

(C) Слюсаренко А.В., 2019 
3 кінця 1990-х - на початку 2000-х було здійснено помітний якісний стрибок у реформуванні й переозброєнні армії Китаю, яку скоротили до 2,5 млн чол. На основі динамічного й науковотехнічного зростання модернізація збройних сил розглядається адміністрацією КНР як важлива складова соціально-економічного розвитку, перехід національної військової сили з рівня регіональної оборони на щабель захисту національних інтересів на глобальному рівні. 32006 р. Китай реалізує програму (на період до 2020 р.) «Модернізація національної оборони і збройних сил». У січні 2016 р. у КНР оголошено про початок масштабного реформування збройних сил, кінцевою метою якого є досягнення до 2020 р. нового рівня керованості, оптимальної структурної побудови й забезпечення здатності армії здобувати перемогу в епоху інформаційних технологій. В цілому смуга реформування армії КНР розрахована на період до 2049 р. Наголос зроблено на набуття Народно-визвольною армією Китаю (НВАК) спроможності до міжвидової взаємодії, мобільності, впровадження інноваційних технологій, організаційну оптимізацію та постійну боєготовність. Враховуючи малу вірогідність глобальної війни, китайські теоретики військової справи вважають, що метою реформ повинна стати готовність до сучасних війн локального характеру, творення мобільних сил, готових діяти по периметру кордонів до третини всієї НВАК (Гаврилов, 2017; Republik.ru, 2016; Газета «2000», 2017).

Не викликає сумніву, що глибока модернізація армії Піднебесної не в останню чергу планується за рахунок посилення піi здатності до дій в умовах «дистанційних» війн шостого покоління, пристосування до асиметричних дій та підвищення ваги розвідувальної та інформаційно-кібернетичної складової. Зокрема, з 2016 р. у макроструктуру НВАК впроваджено т.зв. Війська стратегічної підтримки, на які покладено ведення розвідки (ймовірно - передовсім технічними засобами), інформаційної війни, боротьби у кіберпросторі, а також радіоелектронну протидію. Більшість частин цього командування відносяться до космічної інфраструктури (Militaryarms.ru, 2018).

Виходячи із зростання ваги Китаю на світовій арені, форсованого та інноваційного розвитку військового потенціалу цієї ракетноядерної держави і постійного члена Ради безпеки ООН доцільним виявляється поглиблене вивчення стану й перспектив реформування, оригінальної системи підготовки Сил спеціальних операцій 
(CCO) КНР. Нагадаємо, що творення ССО як самостійного функціонального компоненту збройних сил стало мейнстрімом військового будівництва у багатьох державах, включаючи сусідів України. Зростає і значення урахування зарубіжного досвіду розвитку «елітних військ» при розбудові ССО ЗС України відповідно до внесених у чинне законодавство змін, ухвалених у 2015 - 2016 рр. новітніх доктринальних документів в області військового й безпекового реформування.

Проблема військ спецпризначення КНР в радянські часи порушувалась у закритих для широкого загалу працях авторів - співробітників КДБ, ГРУ Генерального штабу Радянської Армії, і висвітлювалася у розрізі вивчення армії Китаю як цілком імовірного противника на фоні різкого загострення з кінця 1960-х років двосторонніх відносин (Вооруженные силь Китая, 1978:36; Военный потенциал Китая, 1987:336; Сечкин, 1976:584; Басаргин, 1986:196-199; Вооруженная борьба народов Азии за свободу и независимость, 1984:576; Силь спещиальных операций армий капиталистических государств, 1990:432). Вивчення військ спецпризначення тривало і після 1991 р. Співробітниками військових формувань України (передовсім - Збройних Сил, СБ України) С. Александровим, О. Анікєєнком, Г. Биструхіним, А. Васьком, Д. Вєдєнєєвим, I. Данилюком, Р. Іваницьким, М. Єзерським, І. Калініним, І. Пегахіним, С. Тітенком, В. Ткаченком, О. Печоріним та іншими дослідниками підготовлено низку наукових та навчальних праць, де висвітлено особливості військ спецпризначення провідних країн світу, а також історичні традиції розвідувальної діяльності Китаю (зокрема - розвинуте мистецтво партизанської та асиметричної боротьби, засноване на традиційному стратагемному мисленні й необхідності протистояти більш сильному в технічному відношенні противнику у 1920 - 1949 рр.), основні етапи творення його розвідслужб та спеціальних військ, їх стан у 1990-ті - на початку 2000-х років (Александров, 2006:34-40; Анікєєнко, 2005:28; Биструхін\&Вєдєнєєв, 2006:44-51; Васько\&Ткаченко, 1994; Веденеев, 2010a:2-3; Веденеев, 2010b:2-3; Веденеев, 2010:8-9; Веденеев, 2011:32-35; Веденеев\&Будков, 2015:392; Данилюк, Печорін, Сзерський, 2017:75; Калінін, 1995:45-49; Матеріали науковопрактичного семінару «Перспективи та проблеми розвитку $i$ застосування сил спещіальних операцій, 2011:79; Пегахін, Калінін, Іваницький, 2002:175-179; Сергеев, 2005:100; Титенко, 2008:50-59; 
Ткаченко\&Калинин, 1996; Янкович\&Сзерський, 2011:43). Зазначимо, що вивчення порушеної нами теми ускладнюється вкрай обмеженою інформацією про хід реформування ССО Китаю. Проте поза увагою дослідників залишаються новації у розвитку сил спец призначення КНР, перспективи їх реформування.

Метою статті є дослідження сутності та конкретних проявів процесу реформування ССО Китаю в контексті трансформації воєнної організації КНР.

Армія Китаю виросла із підконтрольних Компартії Китаю напівпартизанських формувань часів війни 3 японськими агресорами (1931 - 1945 рр.), тривалої війни із буржуазним урядом Гоміндану (1920 - 1949 рp.) і традиційно велике значення приділяла військовій хитрощі, розвідці, роботі серед населення, тактиці прихованих дій, «тактиці горобців» (удари малими групами і миттєвий відхід), просочуванню, ударам по тилових об'єктах і комунікаціях більш сильного ворога, іншим прийомам, органічно властивим силам спецпризначення. Після створення у 1949 р. КНР тривалий час в НВАК не ставилося питання про війська спецпризначення в класичному розумінні. Функції розвідувально-диверсійної діяльності покладалися на армійські розвідувальні частини й підрозділи.

До другої половини 1980-х років у НВАК існували окремі розвідувально-диверсійні батальйони (до 500 бійців) військових округів, окремі розвідувальні роти (до 100 чол.) в арміях. Згадані батальйони, як вважалося, повинні були закидати у воєнний час розвідувально-диверсійні групи (РДГ) чисельністю 10-12 чол. на відстань до 500 км у тил противника. Розвідувальні управління трьох флотів ВМС КНР мали по одному розвідувально-диверсійному загону (до 200 чол.) Тактична розвідка була представлена розвідувальними батальйонами армійських корпусів (дві роти на танках і БТР, розвідувально-диверсійна рота), які мали виставити до 34 розвідувальних груп і 30 РДГ. У посиленій піхотній дивізії передбачалася розвідувальна рота, у піхотних та танкових полках - розвідувальні роти, які мали вести розвідувальний пошук, влаштовувати засідки тощо (Вооруженные силь Китая, 1978).

Особливі передумови для розвитку мистецтва спеціальних дій створював сам тип китайського воїна, який увібрав тисячолітні традиції конфуціанської цивілізації та китайського націоналізму, військової традиції, описаної Сунь-Цзи у відомій формулі - «Мистецтво війни є мистецтвом омани». Як зазначають спеціалісти, за 
тривалий період національно-визвольної боротьби у китайського вояка сформувалися сміливість, рішучість, величезна витривалість й невибагливість, спокійне ставлення до втрат, схильність до підступної тактики, неабияка військова хитрість. Ці властивості поєднувалися із самопожертвою, дисциплінованістю, сліпим підпорядкуванням, жорстокістю та садизмом, китайським шовінізмом i месіанською переконаністю в особливій культурній перевазі великого Китаю, китайця над іноземними «варварами».

Глибинні зрушення, викликані модернізацією КНР, повною мірою торкнулися реформування збройних сил, модернізації ракетно-ядерного потенціалу, масштабним переозброєнням армії, потужною програмою військового суднобудівництва тощо. Що стосується добірних спецвійськ, то найбільш потужний контингент сил спецпризначення традиційно існує у складі Сухопутних військ Китаю. Відповідно до відкритих концептуальних документів $з$ військової стратегії, Сухопутні війська (СВ) НВАК визначаються для ведення бойових дій на континенті, у взаємодії з іншими видами збройних сил, у складі об'єднаних міжвидових угруповань 3 метою розгрому противника та оволодіння територією, яку той займає, тощо.

Водночас становлення КНР у статусі нової світової наддержави та усвідомлення проводом КНР важливості впливу на ситуацію у зонах інтересів своєї держави, перспективних сировинних регіонах, об'єктивно приводить до зростання кола завдань сухопутних військ та їх високомобільних компонентів, до яких і відносяться ССО. 3 1990 р. підрозділи (кораблі) НВКА почали брати участь у міжнародних операціях під егідою ООН, міжнародних акціях гуманітарного характеру, боротьбі з піратством. Енергійно включилася КНР і до військових навчань учасників Шанхайської організації співробітництва та ОДКБ, проведення антитерористичних навчань (зокрема - у Таджикистані з огляду на зростання загрози вторгнення озброєних угруповань радикальних ісламістів, існування у самому Китаї гострої проблеми уйгурського ісламського сепаратизму й тероризму).

У Сухопутні війська НВКА (1600 тис. вояків), командування якими покладено на командувача - заступника міністра оборони КНР, включені Сили спеціальних операцій, у складі штабу СВ (створений у 2015 р.) діє розвідувальне управління. Раніше 
існувало 18 загальновійськових армій СВ (інколи їх іменують армійськими групами, чисельність - 30 - 50 тис. вояків), до складу яких, як правило, входило три механізовані дивізії та частини армійського комплекту, включаючи окремий розвідувальний батальйон (300 - 400 осіб). Армійські розвідпідрозділи проходять підготовку за скороченою й полегшеною програмою підготовки власне військ спецпризначення. Значення ССО зростає й у зв'язку із відпрацюванням НВАК (зокрема, на масштабних військових навчаннях чотирьох округів у 2009 р.) наступальних операцій на глибину до 2000 км, що означає підготовку до можливих дій на території Росії.

Сили спеціальних операцій як компонент СВ НВАК створені у 1988 р. (уперше - в Гуанчжоуському військовому окрузі), відповідно, у кожному із семі військових округів (BО) розміщено посилені загони ССО («дадуй»), чисельністю до 1000 багнетів кожний, і підпорядковані командувачам округів. Вони запроваджувалися за окремими штатами й структурою, отримували спеціальні озброєння та техніку, їх особовий склад проходив спеціалізований курс навчання. Особливу увагу приділяли фізичній та моральнопсихологічній підготовці кандидата, відбору особового складу за методиками британської Спеціальної авіадесантної служби (SAS). Своєрідною першою прилюдною демонстрацією можливостей CCO КНР стала їх участь у міжнародних змаганнях спецназу ERNA в Естонії у 1998 р., де представники Китаю виграли 8 із 20 видів змагань та отримали ще кілька призових місць.

Нині ж іде перехід до бригадної ланки організації СВ (зокрема в інтересах можливості формування міжвидових угруповань сил, маневреності, створення бригад легкого й важкого типів залежно від завдань та природно-кліматичних умов потенційного ТВД), в якій бригада має окрему розвідувальну роту. Не виключено, що структура ССО СВ НВАК зазнає нових змін у зв'язку із реорганізацією структури управління збройними силами. Сьогодні у підпорядкуванні Центральної військової ради КПК замість семи ВО знаходяться п’ять командувань на ТВД (Північне, Центральне, Західне, Південне й Східне), до яких перейдуть загони ССО «дадуй». Командування стали вищими оперативно-стратегічними об'єднаннями НВАК, і під їх управлінням перебувають всі частини СВ, ВПС та ВМС НВАК відповідної території. В СВ НВАК залишилося 13 армій, у кожній з яких передбачено тепер шість 
загальновійськових бригад і шість спеціалізованих бригад, однією 3 яких є бригада спеціального призначення (Храмчихин, 2017).

Загони ССО територіальних командувань мають екзотичні назви на кшталт «Яструб», «Сокіл», «Летючий дракон», «Гострий меч південного Китаю», «Нічний тигр» тощо. Штаби округів отримали спеціальні органи управління й планування операцій за участю загонів ССО. Застосування ССО, забезпечення їх інтеграції в операції стратегічного й оперативно-тактичного рівня значно полегшилося із активним впровадженням автоматизованих систем управління військами (АСУВ), зокрема АСУВ «Цюйдянь», яка забезпечує інформаційні потоки між Генеральним штабом НВАК, штабами видів збройних сил, родів військ та командуваннями округів (територіальних командувань) (Interpolit.ru, 2015).

Нижчим підрозділом є група з 2-3 розвідників. В основу підготовки бійців покладені традиційні китайські методики та адаптований до місцевих умов кращий світовий досвід. Окрім традиційних розвідувально-диверсійних завдань, бійці спецназу можуть вести контрпартизанську та антитерористичну боротьбу, формувати антиурядове підпілля та повстанські рухи на основі націоналістичних організацій. Відпрацьовуються навички жорстокого залякування противника, застосування тортур, проведення терористичних акцій. За необхідності загони ССО можуть отримувати БТР і БМП, спеціальні автомобілі типу «баггі» тощо.

3 погляду зростання можливостей ССО (які перекидаються переважно вертольотами) варто відзначити розвиток Армійської авіації як окремого роду $\mathrm{CB}$, яка включає авіацію військових округів і поділяється на бригади та окремі полки вертольотів змішаного складу (мають на озброєнні вертольоти вогневої підтримки, транспортно-бойові, транспортно-десантні, РЕБ, рятувальносанітарні тощо). Станом на початок 2015 р. авіація СВ мала 150 бойових машин (Z-10-90, Z-19-60), багатоцільових машин - 351, транспортних - до 340. Іде оснащення ССО безпілотними літальними апаратами (БПЛА), адже, на думку китайських фахівців, в інтересах «воїнів тіні» можуть ефективно працювати мало габаритні і малошумні апарати з радіусом дії $2-5$ км.

Залежно від географічного розташування кожен загін має власну зону відповідальності і готується до дій проти конкретного противника. Бійці вивчають відповідну іноземну мову, національний характер, збройній сили потенційного противника, систему охорони 
його командних пунктів, аеродромів, РЛС, ракетних позицій тощо. Для дій на південному напрямку диверсанти проходять посилену альпіністську підготовку, на південно-східному напрямку приділяють увагу діям в умовах джунглів. На північному напрямку наголос робиться на лижній підготовці, загартовуванню у морози тощо. Всі елітні бійці опановують мистецтво спеціальних дій в індустріальних містах. Усі програми бойової підготовки спрямовуються на індивідуальну підготовку підривників, снайперів, зв'язківців, операторів БПЛА, РЛС, засобів РЕБ (Шльндов, 2015).

Добровільний, ініціативний вступ до елітних частин виключений. Туди відбирають вояків інших частин після тривалого спостереження офіцерів ССО. Навчання ведеться на межі психофізіологічних властивостей людини, 3 - 6 міс. на рік, включає давні методики гімнастики Ушу, Цигун, техніки тібетських монахів, різні китайські й японські школи рукопашного бою. Бійці вчаться веденню бою під водою без аквалангів за допомогою спеціальних дихальних вправ. Залежно від дислокації і потенційного ТВД вояки загонів ССО проходять лижну або альпіністську підготовку. Особлива увага приділяється навичкам виживання у різних природнокліматичних умовах (гори, тайга, безлюдний острів тощо). Бойова $\mathrm{i}$ спеціальна фізична підготовка бійців китайських ССО здійснюється практично на межі людських можливостей (віджимання на брусах 200 разів; віджимання від підлоги - 100 разів за хвилину; влучення кидком гранати у вікно автомобіля $330 \mathrm{M}$; форсування водної перешкоди у 5 км у повному спорядженні; підйом на стіну будинку на 5 поверх без допоміжних засобів за 30 с тощо).

Як зазначає авторитетний воєнно-політичний журнал «Interpolit», китайська армія створила потужний кадровий сержантський склад, який забезпечує зразкову дисципліну, дбає про високий рівень особистої бойової й тактичної підготовки рядового бійця та первинних підрозділів (у 2009 р. для заохочення кадрового зростання в систему військових рангів ввели 4 сержантських і 4 фельдфебельських звання). Ця обставина особливо важлива для підрозділів спецпризначення, в яких, при їх нечисленності й автономності дій, величезне значення мають індивідуальні якості вояка, рівень його особистої підготовки, морально-психологічна стійкість тощо (Interpolit, 2015).

Характерною рисою масштабної підготовки НВАК до асиметричних дій є опанування спрощеною спеціальною підготовкою 
вояками окремих армійських з'єднань («дивізій підвищеної готовності»): 162-ї (54-ї арміï), 63-ї (21-ї арміï) і 149-ї (13-ї армії). Серйозні елементи спецпідготовки властиві і для особового складу «армій швидкого реагування»: 1-ї (Ханчжоу, Нанкінський ВО), 38-ї (86 тис. чол., Баодін, Пекінський ВО), 39-ї (75 тис., Інкоу, Шеньянський ВО) та 54-ї (89 тис., Сіньсян, Цзінаньський ВО) (Freejournal, 2019).

На думку спеціалістів, до сил спецпризначення НВАК слід віднести й особливо підготовлені підрозділи морської піхоти («ударний морський десант») та повітрянодесантних військ («Гострий меч синього неба»). Прагнучи до обстоювання своїх інтересів на морських просторах, Китай в останні роки значно посилив морську піхоту, яка тепер посідає друге після США місце у світі за чисельністю (десантні морські засоби здатні одночасно прийняти на борт до 12 тис. «морпіхів», іде стрімке будівництво нових десантних кораблів). Морська піхота (МП) КНР створена у 1953 р. і нині має власні частини спецпризначення. Амфібійні розвідпідрозділи МП аналогічні морському спецназу та об'єднані у батальйони спецпризначення бригад МП (250 - 400 бійців, три розвідувальнодиверсійні роти, включаючи одну парашутно-десантну). На базі батальйону можна розгорнути 16 - 18 РДГ для ведення розвідки у прибережних районах, місцях висадки десанту, розмінування ділянок висадки, знищення важливих берегових об'єктів противника. Створені навчально-тренувальні комплекси на о. Хайнань, біля міст Фучжоу та Чжаньцзянь (Веденеев, 2010b).

Військові експерти солідарні у думці, що наявність численних, відмінно навчених, належно оснащених спеціальною зброєю та технікою $\mathrm{CCO} є$ однією із могутніх складових високих бойових можливостей СВ НВАК. Елітний компонент китайської армії нині перетворився на стратегічне знаряддя далекосяжних геополітичних і геоекономічних планів керівництва КНР та спроможний виконувати завдання за призначенням у віддалених географічних зонах, на відстані від основних сил та в будь-яку пору року.

Окремо доцільно зауважити, що реформування й розвиток Сухопутних військ НВАК забезпечують не тільки система військових навчальних закладів, але й низка профільних науково-дослідних установ, які студіюють проблеми оперативного мистецтва, стратегії і тактики, ведуть прискіпливий аналіз застосування військ іноземних держав, розробляють інноваційні методи й способи ведення збройної боротьби у сучасних умовах. 
Висновки. Отже, реформування Сил спеціального призначення НВАК відбувається на фоні масштабної реорганізації структури збройних сил, їх СВ зокрема, розширення кола геополітичних й стратегічних завдань Китаю як перспективної світової потуги. Удосконалюється технічне оснащення ССО, їх бойова навченість, запозичується світовий досвід, ведуться профільні наукові розробки й підготовка кадрів. Власні елементи ССО мають Сухопутні війська, повітрянодесантні війська та ВМС. Сильні підрозділи кібервійни та космічної розвідки запроваджуються в єдиних у своєму роді Військах стратегічної підтримки. Водночас, Китай поки що не запроваджує єдиний орган управління ССО. Спеціальна підготовка стала елементом боєготовності й у звичайних військах, їх об’єднаннях і з'єднаннях постійної готовності, що різко підвищує потенціал армії Китаю у разі ведення «асиметричної» війни.

\section{Використані посилання}

Александров С. 2006. Современные тенденции развития спецназа иностранных государств. Неизвестная разведка. К., № 1-2, C. 34-40.

Анікєєнко О.Ф. 2005. Сили спеціальних операцій армій провідних країн світу та їх застосування. Інформаційно-аналітичний огляд ЦНДІ ЗС України. К., № 1, с. 28.

Басаргин А.Н. 1986. Разведывательная деятельность в политике Компартии Китая и Гоминьдана в годы начиональнодемократической револючии (1921-1949). М., С. 196-199.

Биструхін Г.С., Вєдєнєєв Д.В. 2006. Війна в кам'яних джунглях. Міська партизанська війна як феномен збройної боротьби та спеціальної діяльності. 1945-2005 рр. Монографія. К.: Генеза, С. 44-51.

Гаврилов В. 2017. Китайская оборона уходит в инновационный отрыв. Независимое военное обозрение. 13 января 2017.

Глобальное лидерство к 2050 году. Китай представил стратегию развития на съезде Компартии. Republik.ru, [online] Доступно: <https://republic.ru/posts/87098> [Дата звернення 16 січня 2019].

Васько А.А., Ткаченко В.И. 1994. Силы специальных операций иностранных государств и их боевое применение в современных условиях. Учебное пособие. К.: ИПК СБ Украины. 
Веденеев Д. 2010а. Наблюдая за битвой «двух тигров». Из истории специальных служб Китая (1949-1983 годы). Секретные материальь. № 6, С. 2-3.

Веденеев Д. 2010b. Возрождение великой империи. Армия и флот Китайской Народной Республики. Секретные материаль. № 11, С. 8-9.

Веденеев Д. 2011. Мастера стратагемного искусства. Из истории специальных служб Китая. Камуфляж. № 10, С. 32-35.

Веденеев Д.В., Будков Д.В. 2015. Закулисный актер истории. Очерки истории разведки и контрразведки. К.: К.И.С., 392 с.

Военный потенщиал Китая. 1987. М.: 6 ЦНИИ ГРУ ГШ, C. 241-243.

Вооруженные силь Китая. 1978.К.: КВИРТУ, 36 с.

Вооруженная борьба народов Азии за свободу и независимость. 1984. М.: Наука, 576 с.

Вооруженные силы Китая: структура, численность, вооружение. Militaryarms.ru, [online] Доступно: <https://militaryarms.ru/armiimira/vooruzhennye-sily-kitaya/ https://militaryarms.ru/armii-mira/ vooruzhennye-sily-kitaya/> [Дата звернення 24 жовтня 2018].

Вэйвэй Чжан. 5 причин успешности Китая. 2017. Газета «2000». 4 июля 2017 , с. 5.

Данилюк І.А., Печорін О.М., Єзерський М.Р. 2017. Спеціальні операції провідних країн світу. К.: НУОУ, с. 75.

Калінін I.O. 1995. Перспективи розвитку сил спеціальних операцій на сучасному етапі. Науковий вісник № 3. К.: Академія СБ України, С. 45-49.

Матеріали науково-практичного семінару «Перспективи та проблеми розвитку і застосування сил спеціальних операцій. 2011. К.: НУОУ, с. 79.

Пегахін I.А., Калінін I.О., Іваницький Р.С. 2002. Форми та способи бойового застосування сил спеціального призначення. Труди академії. К.: НАОУ, Вип.38, С. 175-179.

Сергеев А. 2005. Силы спецопераций: взгляд в будущее. Неизвестная разведка. № 3-4, с. 100.

Сечкин Г.П. 1976. Советские Пограничные войска в Великой Отечественной войне 1941-1945 г2. и возможные их действия в современных операциях. М.: Воениздат, 584 с.

Силь спещиальных операций армий капиталистических государств. 1990. М., с. 432. 
Солдаты Поднебесной рвутся в бой. Interpolit.ru, [online] Доступно: <http://interpolit.ru/blog/soldaty_podnebesnoj_rvutsja_v_boj/2015-0928-5672> [Дата звернення 28 вересня 2015].

Спецназ Китая - наиболее опасный в мире. Freejournal, [online] Доступно: <http://freejournal.biz/article1902/index.html> [Дата звернення 16 лютого 2019].

Титенко С. 2008. Силы специальных операцій: развитие продолжается. Неизвестная разведка. № 1, С. 50-59.

Ткаченко В.И., Калинин И.А. 1996. Тактика ведения боевых действий сил специальных операцій армий иностранных государств, их вооружение, оснащение и боевая техника. Учебное пособие. К.: Академия СБ Украины.

Храмчихин А. 2017. Новая Великая китайская стена. Военнополитическое руководство Поднебесной готово к «проецированию силы» в глобальном масштабе. Независимое военное обозрение. 20 Октябрь 2017.

Шлындов А. 2015. «Воины-тени» на защите Поднебесной. Особенности подготовки и боевого применения Сил специальных операций Сухопутных войск НОАК. 27 февраля 2015.

Янкович В.М., Єзерський М.Р. 2011. Сили спеціальних операцій армій провідних країн світу (досвід застосування). К.: НУОУ, с. 43.

\section{References}

Alexandrov S. 2006. Current Trends in the Development of Special Forces of Foreign States. Unknown intelligence. K., No. 1-2, pp. 34-40 (rus).

Anikieenko O.F. 2005. Special forces forces forces of the leading countries of the world and their application. Information-analytical review of the Central Research Institute of the Armed Forces of Ukraine. K., No. 1, p.28

Basargin A.N. 1986. Intelligence activities in the policies of the Communist Party of China and the Kuomintang in the years of the national democratic revolution (1921-1949). M., pp. 196-199 (rus).

Bystukhin G.S, Vedeneev D.V. 2006. The war in the stone jungle. City partisan war as a phenomenon of armed struggle and special activity. 1945-2005. Monograph. K.: Genesis, p. 44-51 (ukr).

Gavrilov V. 2017. China's defense leaves in an innovative gap. Independent military review. 13 January 2017 (rus). 
Global Leadership by 2050. China presented a strategy for development at the Communist Party Congress. Republik.ru, [online] Available at: <https://republic.ru/posts/87098> [Accessed 16 January 2019] (rus).

Vasko A.A., Tkachenko V.I. 1994. Forces of special operations of foreign states and their military use in modern conditions. Tutorial. K.: IPK SB Ukraine (rus).

Vedeneev D. 2010a. Watching the battle of "two tigers". From the History of Special Services of China (1949-1983). Secret materials. No. 6, p. 2-3 (rus).

Vedeneev D. 2010b. Revival of the great empire. Army and Navy of the People's Republic of China. Secret materials. No. 11, p.8-9 (rus).

Vedeneev D. 2011. Masters of stratagem art. From the history of China's special services. Camouflage. No. 10, pp. 32-35 (rus).

Vedeneev D.V., Budkov D.V. 2015. The behind-the-scenes actor of history. Essays on the history of intelligence and counterintelligence. $\mathrm{K}$.: K.I.S., p. 392 (rus).

Military potential of China. 1987. M.: 6 CNII GRU GS, p. 241-243 (rus).

China's armed forces. 1978. K.: KVIRTU, p. 36 (rus).

The armed struggle of the peoples of Asia for freedom and independence. 1984. M.: Nauka, p. 576 (rus).

China's Armed Forces: Structure, Number, Arms. Militaryarms.ru, [online] Available at: <https://militaryarms.ru/armii-mira/ vooruzhennyesily-kitaya/ https://militaryarms.ru/armii-mira/vooruzhennye-silykitaya/ > [Accessed 24 October 2018] (rus).

Weihai Zhang. 5 reasons for China's success. 2017. Newspaper «2000». 4 July 2017, p. 5 (rus).

Danylyuk I.A., Pechorin O.M., Yezerskyi M.R. 2017. Special operations of the leading countries of the world. K.: NUOU, p. 75 (ukr).

Kalinin I.O. 1995. Prospects for the development of special operations forces at the present stage. Scientific Herald No. 3. K.: Academy of Security Service of Ukraine, p. 45-49 (ukr).

Materials of the scientific and practical seminar "Prospects and problems of development and application of special operations forces. 2011. K.: NUOU, p. 79 (ukr).

Peghahin I.A, Kalinin I.O, Ivanitskyi R.S. 2002. Forms and methods of military use of special forces. Labor Academy. K.: NAOU, Issue 38, p. $175-179$ (ukr). 
Sergeev A. 2005. Special operations forces: a look into the future. Unknown intelligence. 3-4, p. 100 (rus).

Sechkin G.P. 1976. Soviet Border Troops in the Great Patriotic War of 1941-1945 and their possible actions in modern operations. M.: Voenizdat, p. 584 (rus).

Special operations forces of the capitalist states armies. 1990. M., p. 432 (rus).

Soldiers of Celestial Empire are torn into battle. Interpolit.ru, [online] Available at: <http://interpolit.ru/blog /soldaty_ podnebesnoj_ rvutsja_v_boj/2015-09-28-5 5672> [Accessed 28 September 2015] (rus).

Special Forces of China - the most dangerous in the world. Freejournal, [online] Available at: <http://freejournal.biz/article1902 /index.html $>$ [Accessed 16 February 2019] (rus).

Titenko S. 2008. Forces of special operations: development continues. Unknown intelligence. Issue № 1, pp. 50-59 (rus).

Tkachenko V.I., Kalinin I.A. 1996. Tactics of conducting combat operations by special operations forces of foreign states armies, their armament, equipment and military equipment. Tutorial. K.: Academy of Security Council of Ukraine (rus).

Khramchikhin A. 2017. The New Great Wall of China. The military-political leadership of the Celestial Empire is ready for a "projection of force" on a global scale. Independent military review. 20 October 2017 (rus).

Shlyndov A. 2015. "Shadow Warriors" in the defense of Celestial Empire. Features of the training and combat use of Special Operations Forces of the Land Forces of the Chinese People's Liberation Army. 27 February 2015 (rus).

Yankovich V.M., Yezersky M.R. 2011. Special operation forces of the world's leading countries armies (experience of application). K.: NUOU, p. 43 (ukr).

\section{Sliusarenko A.}

HISTORY OF THE CREATION OF SPECIAL OPERATIONS FORCES OF THE PEOPLE'S REPUBLIC OF CHINA ARMED FORCES

The military history of the creation and combat activity of Special Operations Forces (SOF) of the People's Republic of China (PRC) armed forces is analyzed. It is noted that on the cusp of $20^{\text {th }}$ and $21^{\text {st }}$ 
centuries a great leap in the world's largest army modernization was made. In January 2016, the PRC announced the start of a large-scale reform of the armed forces which ultimate goal is to achieve a new level of manageability and optimal structural construction as well as to ensure the ability of the army to get the victory in the information technology era by 2020. In general, the RPC army reformation is planned for a period up to 2049. As for the elite Special Forces, it is mentioned that the most powerful SOF contingent is comprised of the PRC armed forces. In accordance with the public conceptual paper on military strategy, the Chinese People's Liberation Army (PLA) is designed to conduct combat operations on the continent, in cooperation with other branches of the armed forces, as part of joint cross-branch groups in order to defeat the enemy, seize the territory, which they occupy etc.

It is noted that in the present conditions the Army range of tasks as well as its high-mobility components, including SOF, is expanding. Since 1990, the PLA units have begun to participate in international operations under the authority of the UN, international actions of a humanitarian nature, and the anti-piracy campaign. The PRC also joined the military exercises of the Shanghai Cooperation Organization and Anti-terrorist Exercises (in particular, in Tajikistan, due to the growing threat of radical Islamist groups invasion, the existence of Uyghur Islamic separatism and terrorism in China).

The SOF technical equipment and their combat trainability are improved; world experience is borrowed; specialized research and personnel training are conducted. The SOF own elements consist of the ground, airborne, and naval forces. It is emphasized that China has not established a single authority for SOF management. Special training has become an element of combat readiness in conventional troops, their formation and high-readiness force which dramatically increases the potential of the PRC army in case of asymmetric warfare.

Keywords: The People's Republic of China, the Chinese People's Liberation Army, People's Republic of China Special Operations Forces, the People's Republic of China ground force. 